\title{
Attitude Factors Affecting Teachers' Use of Short Stories in the Teaching of Kiswahili Grammar in Secondary Schools in Nandi North Sub-County, Kenya
}

\author{
Milton Kigaro Lihanda \\ Peace Byrne Agufana \\ Moi University, Kenya
}

Doi: 10.19044/esj.2017.v13n29p172 URL:http://dx.doi.org/10.19044/esj.2017.v13n29p172

\begin{abstract}
This study investigated attitude factors affecting teachers' use of short stories in the teaching of Kiswahili grammar in Secondary Schools in Nandi North Sub County, Kenya. The design for this study was descriptive survey. The total target study population was 50 Kiswahili language teachers in Secondary Schools in Nandi North Sub-County, in Kenya. Sampling was done through stratified and simple random sampling techniques to arrive at $50 \%$ of the target population. A total of 15 Kiswahili language teachers $(n=15)$ respondents participated in the study. Data was collected through the use of questionnaires for teachers. The data was analyzed using descriptive statistical methods such as frequencies, and percentages. The study found out that very few teachers used short stories in teaching Kiswahili grammar. The research found out that teachers' attitude towards use of short stories in teaching and learning Kiswahili grammar was positive. Based on the findings, the study recommends that teachers should use short for effective Kiswahili grammar teaching.
\end{abstract}

Keywords: Kiswahili Grammar, Short Stories, Attitude

\section{Introduction}

Despite the critical role Kiswahili plays nationally, regionally and internationally as the national and official language in Kenya and in several of the East African Cooperation states, its performance in national examinations is still below expectation. This can be attributed to the attitudes of Kiswahili language teachers and learners.

Attitude has been defined differently by different scholars. Gardner (1980) defines attitude as the sum total of a man's instincts, feelings, 
prejudice or brains, preconceived notions, fear, threats and convictions about any specified topic. Ajzan (1988) views attitude as a disposition to respond favorably or unfavorably to an object, person, institution or event. Baker (1992) looks at attitude as a hypothetical construct used to explain the direction and persistence of human behavior. It's worth noting that attitude cannot be directly observed but must be inferred from overt behavior, both verbal and non-verbal.it is in the light of the above that this study was carried out to establish the attitude factors affecting the teaching and learning of Kiswahili grammar.

It is clear that attitude influences teacher classroom action and mode of teaching. Savington, (1991) in relation to importance of teacher' attitude and beliefs argues that in the quest for the improvement of language teaching, teachers' perceptions of what they do and why they do it holds the promise for understanding the frequency, noting discrepancies between theoretical understanding of second language acquisition and classroom practice. Similarly, Karavas (1996) found that teacher beliefs and theories although in many cases unconsciously held, have an effect on their classroom behavior.

Teachers further expressed their feelings that it was necessary for language teachers to master the skills of using short stories to teach Kiswahili grammar. These findings correlate to those of Meenakshi, (2008) who found out that an individual' perception of the class teacher, peer group, syllabus and his/ her awareness for future needs affect his/her attitude to language learning.

Kiswahili language is spoken by various communities inhabiting the African great lakes region including Kenya, Tanzania, Uganda, Rwanda, Burundi, Mozambique and Democratic Republic of Congo, Ogechi (2002). Although only around five million people speak Kiswahili as their mother tongue, the language is used as a lingua franca in much of southern half of East Africa. Ogechi, (2002) approximates the total number of Kiswahili speakers in the world at 150 million. Kiswahili is one of the official languages of the African union. It serves as a national language or official language in four nations- Democratic Republic Congo, Uganda, Tanzania and Kenya.

Kiswahili is offered as a subject in various institutions worldwide. Mwansonko as cited by Ogechi (2002) states that by 1997, 48 institutions of higher learning were teaching and conducting research in Kiswahili worldwide. Of these 24 were in Europe, 18 in United States of America, two in Asia and five in Africa (Ogechi 2002). German had more than 10 universities offering Kiswahili by 1977 . Kiswahili is offered also as foreign language in approximately 100 universities across USA. 
In Kenya and Tanzania Kiswahili is a compulsory and examined subject in primary and secondary school. It is the medium of instruction in primary schools in Tanzania. In the Constitution of Kenya (2010), Kiswahili has been recognized as both the national and co-official language alongside English. Modern technology has also embraced Kiswahili which is now recognized by Microsoft. Ominde, (1964) recommended that Kiswahili be made compulsory subject in primary schools for its unifying national influence and as a means of Pan African Communication. According to Kenya Institute of Education (2002), Kiswahili has the capacity to nurture and develop national unity and patriotism. Kiswahili is taught as a second language to Kenyan learners. Even native Swahili speakers find the subject standardized from Kiunguja dialect spoken in Zanzibar- different from the local dialects depending on their location. Nandi County is mainly occupied by Nandi speaking sub-tribe of the Kalenjin ethnic group. Given the linguistic differences between Nandi and Kiswahili languages, there is bound to be negative transfer in Second Language Acquisition (SLA). Mutugu, (2001) citing Selinker, Tucker and Byan cited in Mutugu (2001) states that sounds like /b//d/ /j//z//g/ are problematic to Nandi speakers. These sounds are problematic because they do not exist in Nandi language and the same problem is transferred to second language learning.

Nandi County will therefore need to develop appropriate teaching strategies that will address these and other L1 challenges among his learners. Grammar and writing skills depend fundamentally on the learners' proficiency in reading skills (Kabaji 2011). An effective reader knows how to use punctuation marks, words, proverbs, paragraphing and correct sentence structures. Buhere (2001) states that writers are ardent readers moved to imitation. He wonders how we would expect our students to write functionally when they have never seen the best models or specimen or read a good writing. Short stories have been examined for over six years and these cannot be said to be enough exposure in exam oriented system. Due to this, integrative method of teaching will be required.

For several years now (2009 - 2013), the performance of students sitting for the Kenya Certificate of Secondary Education (KCSE) and the Kenya Certificate of Primary Education (KCPE) in Kiswahili subject has been a source of concern due to the perennial poor results. This is in contrast to the objectives of the Kiswahili syllabus in both primary and secondary schools in Kenya that expects learners at the end of their various courses to, among other things, be able to: listen with understanding; express themselves clearly, logically and coherently in writing and speech; to read with comprehension; and to communicate appropriately (Musau. 1999).

In attempt to address this problem, the Kiswahili Syllabus (2006) at secondary school level has embraced the use of oral literature as a way of 
strengthening language competence. However, this has not yet been achieved and in the KNEC 2013 KCSE analysis recommended use of integrative method in teaching Kiswahili grammar if better results are expected in the national examination. It is in view of this, that this study seeks to delve into the use of short stories in the teaching of grammar skills. Simala (2002) identified the need for effective language teaching to start right from the formative years of a learner's education. The teaching and learning of Kiswahili is greatly enriched by use of short stories as they create room for pupil involvement and participation in sourcing of the materials from our rich and diverse cultural backgrounds. This makes learning real and concrete.

Short stories are considered as good resources that can be used in a language classroom. Wheeler, (2001) thinks that short stories are a natural part of a child's life". Good stories can draw the child's attention, stimulate his/her imagination and his/her desire to use the language (Wheeler, 2001). One more important advantage of the use of story suggested by Laine (1997) is that in classes where there are children who are not motivated by the foreign language and who are low achievers, a story, if it is well-chosen, can change their attitude to the language.

Ayot, (1984) says that the development of competence depends to a large extent whether the students are given sufficient opportunity to become productively involved in practical language using situations. The burden of improving student's language rests entirely on the shoulders of the teacher, whereas the meaningful contexts, which can motivate learners to use language in hypothesizing, generalizing and sharing ideas about common experiences, occur naturally and more often across the curriculum in various subjects.

Oral literature uses language in context. For this reason, it is hard to divorce literature from language. Using novels, short stories, poems and other forms of literature to teach language, is an invaluable and enjoyable experience. KNEC (2014) 2013 KCSE examination analysis report recommends an integrated approach to the teaching of Kiswahili grammar. This is as a result of under achievement in Kiswahili grammar at the national level where by performance in KCSE grammar section was not well achieved with an average mean of 29.92. This shows that aspects of grammar can be taught as they appear in a literary piece. For example, where there are two characters conversing in a story, the teacher can use this dialogue to teach direct and reported speech. The teacher can also use the opportunity of reading a story to teach faster reading, silent reading, reading aloud etc. Such a story can also afford an opportunity to teach vocabulary and pronunciation. Literary works also help to develop the learner's critical thinking which a crucial element in intellectual development. In essence therefore, short stories can be used in learning language skills such as 
grammar, reading \& writing, listening, and speaking.

With these in mind, the researcher hopes that the findings, conclusions and recommendations to be made out of this study will go a long way in contributing to the strengthening of the use of short stories in the teaching and learning, and making the learning process enjoyable to both the instructor and the learner. In addition, effective use of these aspects of oral literature will give the subject its much-needed social context (Barasa, 2005).

From the above literature review, it is evident that little research has been done on teachers' attitude factors affecting use of short stories in the teaching of Kiswahili grammar in secondary schools in Kenya. It is against this background that the researcher in this study tries to address this gap by investigating the attitude factors affecting the teaching of Kiswahili grammar, with a view of reporting the actual practice by teachers in Secondary Schools in Kenya.

The purpose of this study therefore was to establish the attitude factors affecting teachers' use of Short Stories in teaching Kiswahili grammar in secondary schools in Nandi North Sub County, Kenya.

\section{Materials and Methods}

The study adopted a descriptive survey design. Kombo and Tromp (2006) define research design as the structure of research. It is the 'glue' that holds all the elements in a research project together. Orodho (2004) defines it as the scheme, outline or plan that is used to generate answers to research problems. He states that survey is a method of collecting information by interviewing or administering a questionnaire to a sample of individuals. It is the most frequently used method of collecting information about people's attitude, opinion, habits or any of the variety of education or social issues.

Survey design was appropriate because it enabled the researcher obtain pertinent and precise information concerning the effects of using short stories to teach grammar in Nandi North District of Nandi county and helped draw conclusions on the facts discovered.

Stratified random sampling method was used to select the percentage of schools that were included in the study because the Sub - county has single and mixed, county and sub-county schools which were either day or boarding. Two strata sampling was applied for the study including: First, gender status of the school and second; size of the school as per the number of students in each class. A total of 12 schools (33\%) out of 36 school that had sat for KCSE for the past five years with 2326 students were sampled as follows: 2 boys boarding, 2 girls boarding and 8 mixed day secondary schools. Two teachers of Kiswahili from two (2) boys schools, two (2) teachers of Kiswahili from two (2) girls schools and one (1) teacher of Kiswahili from each of eight (8) mixed day schools were selected using 
purposive sampling. Total sample size was $15(n=15)$ Kiswahili language teachers representing $(50 \%)$ of the total number of teachers from the 12 sampled schools.

The study used questionnaires to collect information from teachers of Kiswahili grammar from sampled schools. The questionnaire had a Likert scale which was used to collect data on teachers' attitudes towards the teaching and learning of Kiswahili grammar using short stories. Richards, Platt and Weber (1992) note that a Likert like scale, is a common scale used to measure a person's reaction to something. The questionnaire had 15 items (statements) seeking teachers' views. Respondents were required to respond to every statement using a structured format: Strongly Agree (SA), Agree (A), Uncertain (U), Disagree (D) and Strongly Disagree (SD).

After all the questionnaires and interview schedules were collected, data appropriately coded and entered into the computer for analysis. Qualitative data obtained was analyzed thematically. Data was organized into themes, categories and patterns relevant to the study then the findings were presented through tabulation. Quantitative data obtained were coded then analyzed with the help of Statistical Package for Social Sciences (SPSS) and the results from the analysis presented using percentages, means, frequency distribution tables, bar graphs, and pie-charts. Findings were reported thematically on the basis of the research objectives.

Inferences were then made from the trends observed from the analyzed data and were used to reach conclusions and make generalizations about the characteristics of populations based on data collected from the respondents.

\section{Results}

The objective of the study was to establish teacher's attitude towards use of short stories in teaching and learning of Kiswahili grammar in Secondary Schools in Kenya. The study set to establish teachers' attitude towards use of short stories in teaching Kiswahili grammar. Respondents were required to rate their feelings on a Likert scale ranging from Strongly Agree (SA), to Strongly Disagree (SD). To bring those perspectives clearly into perspective. This is provided in Table 5.1. 
Table 5.1 Teachers' attitude towards use of short stories in the teaching of Kiswahili grammar. $(n=15)$

\begin{tabular}{|c|c|c|c|c|c|c|c|c|c|c|c|}
\hline \multirow[t]{2}{*}{ No. } & \multirow[t]{2}{*}{ STATEMENT } & \multicolumn{5}{|c|}{ FREQUENCY } & \multicolumn{5}{|c|}{ PERCENTAGE } \\
\hline & & SA & A & UD & $\mathrm{D}$ & SD & SA & A & UD & $\mathrm{D}$ & SD \\
\hline 1 & $\begin{array}{l}\text { Use of short stories } \\
\text { is a very effective } \\
\text { way of teaching } \\
\text { Kiswahili grammar. }\end{array}$ & 3 & 11 & 0 & 1 & 0 & 20 & 73.3 & 0 & 6.7 & 0 \\
\hline 2 & $\begin{array}{l}\text { It is necessary to } \\
\text { use short stories in } \\
\text { teaching and } \\
\text { learning grammar. }\end{array}$ & 3 & 9 & 2 & 1 & 0 & 20 & 60 & 13.3 & 6.7 & 0 \\
\hline 3 & $\begin{array}{l}\text { My learners } \\
\text { understand } \\
\text { grammar better } \\
\text { when } 1 \text { use short } \\
\text { stories to teach } \\
\text { Kiswahili grammar. }\end{array}$ & 9 & 5 & 0 & 1 & 0 & 60 & 33.3 & 0 & 6.7 & 0 \\
\hline 4 & $\begin{array}{c}\text { I find it very } \\
\text { relevant to use } \\
\text { Short stories when } \\
\text { teaching Kiswahili } \\
\text { grammar }\end{array}$ & 4 & 10 & 1 & 0 & 0 & 26.7 & 66.7 & 6.7 & 0 & 0 \\
\hline 5 & $\begin{array}{l}\text { I enjoy using short } \\
\text { stories to teach } \\
\text { Kiswahili grammar }\end{array}$ & 2 & 10 & 2 & 1 & 0 & 13.3 & 66.7 & 13.3 & 6.7 & 0 \\
\hline 6 & $\begin{array}{l}\text { Using short stories } \\
\text { to teach Kiswahili } \\
\text { grammar is time } \\
\text { consuming }\end{array}$ & 7 & 3 & 2 & 3 & 0 & 46.7 & 20 & 13.3 & 20 & 0 \\
\hline 7 & $\begin{array}{c}\text { Short stories help } \\
\text { cater for individual } \\
\text { differences amongst } \\
\text { Kiswahili grammar } \\
\text { learners. }\end{array}$ & 2 & 12 & 0 & 1 & 0 & 13.3 & 80 & 0 & 6.7 & 0 \\
\hline 8 & $\begin{array}{l}\text { I use short stories to } \\
\text { correct common } \\
\text { Kiswahili grammar } \\
\text { mistakes. }\end{array}$ & 3 & 10 & 1 & 0 & 1 & 20 & 66.7 & 6.7 & 0 & 6.7 \\
\hline 9 & $\begin{array}{l}\text { I find use of short } \\
\text { stories in teaching } \\
\text { Kiswahili grammar } \\
\text { taxing and slows } \\
\text { down syllabus } \\
\text { coverage. }\end{array}$ & 2 & 10 & 1 & 1 & 1 & 13.3 & 66.7 & 6.7 & 6.7 & 6.7 \\
\hline 10 & $\begin{array}{l}\text { Short stories should } \\
\text { be included in } \\
\text { Kiswahili grammar } \\
\text { lessons. }\end{array}$ & 4 & 8 & 3 & 0 & 0 & 26.7 & 53.3 & 20 & 0 & 0 \\
\hline 11 & $\begin{array}{l}\text { It is necessary for } \\
\text { language teachers to } \\
\text { master the skill of } \\
\text { using short stories } \\
\text { to teach Kiswahili } \\
\text { grammar. }\end{array}$ & 6 & 8 & 1 & 0 & 0 & 40 & 53.3 & 6.7 & 0 & 0 \\
\hline
\end{tabular}




\begin{tabular}{|c|c|c|c|c|c|c|c|c|c|c|c|}
\hline 12 & $\begin{array}{c}\text { I easily access } \\
\text { textual short stories } \\
\text { for use in the } \\
\text { teaching of } \\
\text { Kiswahili grammar. }\end{array}$ & 1 & 9 & 2 & 3 & 0 & 6.7 & 60 & 13.3 & 20 & 0 \\
\hline 13 & $\begin{array}{c}\text { Recorded short } \\
\text { stories should be } \\
\text { included in classes } \\
\text { of listening. }\end{array}$ & 2 & 11 & 1 & 1 & 0 & 13.3 & 73.3 & 6.7 & 6.7 & 0 \\
\hline 14 & $\begin{array}{c}\text { In addition to } \\
\text { expository } \\
\text { passages, short } \\
\text { stories should be } \\
\text { included in classes } \\
\text { of reading. }\end{array}$ & 2 & 13 & 0 & 0 & 0 & 13.3 & 86.7 & 0 & 0 & 0 \\
\hline 15 & $\begin{array}{c}\text { It is not necessary } \\
\text { to use short stories } \\
\text { in teaching } \\
\text { Kiswahili grammar. }\end{array}$ & 0 & 2 & 0 & 12 & 1 & 0 & 13.3 & 0 & 80 & 6.7 \\
\hline
\end{tabular}

From the results of the study, Kiswahili teachers had varied feelings towards using short stories in teaching Kiswahili grammar, and their responses were described as follows:

As to whether using of short stories was a very effective way of teaching and learning Kiswahili grammar, 20\% strongly agreed, 73.3\% agreed, no teacher was uncertain, $6.7 \%$ disagreed while no teacher strongly disagreed.

When they were asked if it was necessary to use short stories in teaching and learning Kiswahili grammar, 20\% strongly agreed, $60 \%$ agreed, $13.3 \%$ were uncertain, $6.7 \%$ disagreed while no teacher strongly disagreed. Most teachers felt that it was necessary to use short stories in teaching Kiswahili grammar.

When teachers were asked to express their feeling on if their learners understand grammar better when they use short stories when teaching grammar, $60 \%$ strongly agreed with this statement, 33.3\% agreed, $6.7 \%$ disagreed.

Teachers were also asked to express their feelings on whether short stories make learning more relevant to learner needs and experiences and responded as follows: $26.7 \%$ strongly agreed, $66.7 \%$ agreed, while $6.7 \%$ were uncertain.

On whether they enjoy using short stories to teach Kiswahili grammar, $13.3 \%$ strongly agreed, $66.7 \%$ agreed, $13.3 \%$ were uncertain, $6.7 \%$ disagreed while no teacher strongly disagreed.

Teachers were asked to express their feelings on whether using short stories to teach Kiswahili grammar was time consuming and their response was as follows: $46.6 \%$ strongly agreed, $20 \%$ agreed, $13.3 \%$ were uncertain and $20 \%$ disagreed. 
When asked if short stories catered for individual differences amongst Kiswahili grammar learners, respondents gave the following responses: $13.3 \%$ strongly agreed, $80 \%$ agreed and $6.7 \%$ disagreed. No respondent was uncertain and no respondent strongly disagreed.

As to whether short stories created room for correction of common Kiswahili grammar mistakes, the following responses were given: $20 \%$ strongly agreed, $66.7 \%$ agreed, $6.7 \%$ were uncertain and $6.7 \%$ strongly disagreed.

Teachers were asked to express their feeling on whether use of short stories in teaching Kiswahili grammar is taxing and slows down syllabus coverage and responded as follows: $13.3 \%$ strongly agreed, $66.7 \%$ agreed, $6.7 \%$ were uncertain $6.7 \%$ disagreed while $6.7 \%$ strongly disagreed.

As to whether short stories should be included in Kiswahili grammar lessons other than expository passages, $26.7 \%$ strongly agreed, $53.3 \%$ agreed while $20 \%$ were uncertain.

Respondents were asked if it was necessary for language teachers to master the skills of using short stories to teach Kiswahili grammar and responded as follows; $40 \%$ strongly agreed, $53.3 \%$ agreed and $6.7 \%$ were uncertain.

Teachers expressed their feelings on availability of textual short stories for use in the classes of listening was important. This is how they responded; $6.7 \%$ strongly agreed, $60 \%$ agreed, $13.3 \%$ were uncertain while $20 \%$ disagreed.

Respondents were further asked to express their feelings on whether recorded short stories should be included in classes of language, their responses were; $13.3 \%$ strongly agreed, $73.3 \%$ agreed, $6.7 \%$ were uncertain while $6.7 \%$ disagreed.

Teachers were further asked to give their opinion on whether short stories should be included in classes of reading besides expository passage and their responses were $13.3 \%$ strongly agree and $86.7 \%$ agreed.

When teachers were asked whether it was necessary to use short stories in teaching Kiswahili grammar 13.3\% agreed, $80 \%$ disagreed and $6.7 \%$ strongly agreed.

\section{Discussion}

From the study findings, we can infer that, use of short stories to teach Kiswahili grammar was viewed as effective. Short stories also helped cater for individual differences of learners in Kiswahili language learning. Short stories were more effective in Kiswahili grammar lessons other than expository passages. It was also found to be necessary for language teachers to master the skills of using short stories to teach Kiswahili grammar. This findings agree with Wheeler (2001), and Laine (1997), who consider short 
stories as good resources that can be used in a language classroom, can draw child's attention, stimulate their imagination and desire to use the language, and if well-chosen a story, can change children's attitude to language learning.

Textual short stories use in classes of listening was important and enhanced Kiswahili language teaching. Recorded short stories inclusion in classes of language was also found to be effective. It was also found out that use of short stories in reading classes in Kiswahili language lessons was better than using expository passages, and that using short stories in teaching Kiswahili language was also very effective. This findings agree with observation made by Simala (2002), and Barasa (2005) who advocate that, effective use of aspects of oral literature give the language its much-needed social context, and that effective language teaching, starts right from the formative years of a learner's education. Simala (2002), goes ahead to state that short stories that children listen to and read during their formative years contribute largely to their language acquisition.

From the foregoing, it can therefore be inferred that use of short stories in language teaching and learning enables students master the language skills better, it also greatly enriches language learning through creating an avenue for pupil involvement and participation in learning through sourcing for short stories from their rich and diverse cultural backgrounds, which can be used during instruction. This enables Kiswahili language learning become real, concrete and participatory. However, on the other side, use of short stories was seen as time consuming, and taxing and that it slowed down syllabus coverage due to the effort put into its use due to the input needed in identifying the right short stories to use in teaching and collecting short stories from the other stakeholders in education.

\section{Conclusion}

From the findings, it is clear that majority of Kiswahili teachers felt that using short stories to teach Kiswahili grammar had a positive effect since it allowed for integrative teaching thus enable learners enjoy learning Kiswahili grammar. This therefore means that teachers held a positive attitude towards teaching Kiswahili grammar using short stories which should be utilized to benefit Kiswahili language teaching and learning.

\section{References:}

1. Ajzan, I. (1988). Attitude, Personality and Behavior. Dorsey Press. Chicago.

2. Ayot, O. H (1984). Language for learning: a methodology book for English language learning in secondary schools. Nairobi: Macmillan Publishers. 
3. Baker, C. (1992). Attitude and language. Clevedon: Multilingual Matters.

4. Barasa, L. P (2005). English Language Teaching in Kenya: Policy, Training and Practice. Moi University Press, Eldoret.

5. Buhere, K. (2001 March 22). Composition Writing. What teachers Students must know. Kenya Times pp 12-13

6. Fabunmi, M. and A. Okore (2000). 'Analysis of the Relationship between Average Class size and Secondary School Academic Performance'. Africa Journal of Educational Planning Policy Studies, 1(2): 107-115.

7. Gardner, R. (1980). On the validity of effective variables in second language learning Acquisition: conceptual and statistical considerations. Language learning, 30(2), 255-270.

8. Karavas-Doukas, E; Using attitude scales to investigate teachers' attitudes to the communicative approach, ELT Journal, Volume 50, Issue 3, 1 July 1996, Pages 187-198. https://doi.org/10.1093/elt/50.3.187

9. Kenya Institute of Education (2002). Secondary School Education Syllabus Vol. 2. Kenya Literature Bureau: Nairobi.

10. Kenya Institute of Education (2006). Secondary Education Syllabus Vol.1. Nairobi: Kenya Literature Bureau: Nairobi.

11. KNEC (2014). The Year 2013 KCSE Examinations Report Vol.1: Languages. Kenya National Examinations Council: Nairobi.

12. Kombo, D. K. \& Tromp, D. L. A. (2006). Proposal and Thesis Writing. Nairobi: Pauline Publications.

13. Laine, E (1997). 'The Place of Storytelling in Language Teaching'. In Falvey, $\mathrm{P}$ \& Kennedy, $\mathrm{P}$ (Eds.) Learning Language through Literature: A Sourcebook for Teachers of English in Hong Kong (pg. 65-72). Hong Kong: Hong Kong University Press.

14. Makokha, J. K. S., Kabaji, E., and Dipio, D (2011). Code-switching in the Contemporary Kenyan Novel After 2000//East African Literature: Essays on Written and Oral Traditions. Berlin: Logos Verlag.

15. Meenakshi, M (2008). Elusive terrain: culture and literary memory. New Delhi. Oxford University Press.

16. Musau, P. M. (1999). Constraints on the Acquisition Planning of Indigenous African Languages. The case of Kiswahili in Kenya. An Internet Document.

17. Mutugu, B.N (2001). Makosa ya Kileksia na Chanzo Chake. Uchunguzi washule za Upili Wilayani Kiambu (unpublished master's thesis) Kenyatta University. Nairobi. 
18. Ogechi, N.O (2002). Mbinu za Mawasiliano kwa Kiswahili. Moi University Press. Eldoret, Kenya.

19. Olembo J., Wanga, P. and Karagu, N. (1992). Management in Education. Nairobi: Education Research and Publication.

20. Ominde, S. O (1964). Kenya Education Commission Report. Government Printer Nairobi

21. Orodho J.A. (2004). Techniques of Writing Research Proposals and Reports in Education, Nairobi, Masda Publishers.

22. Platt, J., Richards, J., and Weber, H (1985). Longman Dictionary of Applied Linguistics. Beijing: Longman World Publishing Corp.

23. Savington, S. J. (1991). Communicative Language Teaching: State of the Art, TESOL Quarterly 25(2): 261-77.

24. Simala, I. K (2002). Empowering indigenous African Languages for Sustainable Development. In F. R. Owino (Ed.) Speaking African: African languages for education and development. Cape Town: Centre for Advanced Study of African Languages.

25. The Constitution of Kenya, 2010. National Council for Law Reporting. Retrieved from: www.kenyalaw.org

26. Wheeler, J (2001) Stories in the Language Classroom-Integrating Language Skills. In a Mok (Eds.). Task-based learning, Language, arts and the Media. A source book for Secondary English teachers (p 35-48) Hong Kong INSTEP. Faculty of Education, University of Hong Kong.

27. Kenya Institute of Education (2002). Secondary School Education Syllabus Vol. 2. Kenya Literature Bureau: Nairobi. 